\title{
STUDIES IN THE
}

\section{RENAISSANCE}

\author{
VOLUME XVII
}

PUBLICATIONS OF

THE RENAISSANCE SOCIETY OF AMERICA

1161 Amsterdam Avenue, New York, New York 10027 


\title{
THE RENAISSANCE SOCIETY OF AMERICA
}

\author{
EXECUTIVE BOARD
}

M. A. Shaaber (Pennsylvania, emeritus), President 1969-1970

Eugene F. Rice, Jr. (Columbia), Executive Director 1970-1972

Richard E. Priest (New York City), Treasurer 1970-1972

Elizabeth Story Donno (Columbia), Editor, Renaissance Quarterly

Felix Gilbert (Inst. for Advanced Study, Princeton), Medici Project

Richard Harrier (New York Univ.), Editor, Studies in the Renaissance

Paul Oskar Kristeller (Columbia), Delegate to the ACLS 1969-1971

Rensselaer W. Lee (American Academy, Rome), Chairman, International Cooperation 1969-1971

James V. Mirollo (Columbia), Co-editor, Renaissance Quarterly

Anthony Molho (Brown Univ.), Chairman, Membership and Regional Conferences 1970-1972

William Nelson (Columbia), Chairman, International Cooperation 1970-1972

George B. Parks (Queens, emeritus), Editor, Publication Series

John Herman Randall, Jr. (Columbia), Chairman, New Projects and Activities I968-1970

Gustave Reese (New York Univ.), Chairman, Constitution and Bylaws 1969-1971

William Salloch (Ossining, N.Y.), Chairman, Committee on Development I968-1970

Josephine Waters Bennett (Univ. of Illinois, Chicago Circle), Trustee of Invested Funds 1968-1970

Curt F. Bühler (Pierpont Morgan Library), Trustee of Invested Funds 1970-1972

Phyllis W. G. Gordan (New York City), Trustee of Invested Funds 1969-197I

\section{COUNCIL}

\section{RBPRESENTATIVES OF REGIONAI CONFBRENCES}

Central: Lloyd E. Berry (Illinois)

Chicago University Seminar: Michael Murrin (Chicago)

Columbia University Seminar: Charles Trinkaus (Sarah Lawrence)

Middle Atlantic: A. G. Reichenberger (Pennsylvania) and Charles Mitchell (Bryn Mawr)

Newberry Library: Edward Lowinsky (Chicago)

New England: David S. Berkowitz (Brandeis) and Clare M. Murphy (Rhode Island)

New York Renaissance Club: Rainer Pineas (York)

North Central: F. David Hoeniger (Toronto) and John Arthos (Michigan)

Northern California: John B. Gleason (Univ. of San Francisco)

Pacific Northwest: Larry L. Lawrence (Central Washington State)

Pennsylvania University Seminar: Humphrey Tonkin and Werner Gundersheimer (Pennsylvania)

South Central: Marjorie Lewis (Texas Christian); SidneyJ. Landman (Texas Wesleyan)

Southeastern: Thomas Wheeler (Tennessee)

Southern California: French Fogle (Claremont)

Toronto Renaissance and Reformation Colloquium: Maria R. Maniates (U of Toronto)

UCLA Center for Renaissance Studies: Lynn B. White, Jr. (UCLA)

(continued on inside back cover) 


\section{STUDIES IN THE RENAISSANCE}

VOLUME XVII

PUBLICATIONS OF

THE RENAISSANCE SOCIETY OF AMERICA NEW YORK $\cdot$ MCMLXX 


\section{EDITORIAL BOARD}

JOSEPHINE WATERS BENNETT

CURT F. BÜHLER

FELIX GILBERT

PHYLLIS W. G. GORDAN

RICHARD HARRIER, Editor

PAUL OSKAR KRISTELLER

RENNSELAER W. LEE

JAMES V. MIROLLO
ANTHONY MOLHO

WILIIAM NELSON

GEORGE B. PARKS

RICHARD E. PRIEST

JOHN HERMAN RANDALL, JR.

GUSTAVE REESE

EUGENE F. RICE, JR.

WILLIAM SALLOCH

M. A. SHAABER

COPYRIGHT I970 BY THE RENAISSANCE SOCIETY OF AMERICA PRINTED BY THE STINEHOUR PRESS - LUNENBURG - VERMONT 


\section{CONTENTS}

The 'Lost' Fifth Book of the Life of Pope Paul II by Gaspar of Verona

AVERY ANDREWS

Grammar and Music in Thomas Campion's Observations in the Art of English Poesie

JANE K. FENYO

The Florentine 'Tassa dei Traffichi' of I45I

ANTHONY MOLHO

Erasmus' Biblical Humanism

C. A. L. JARROTT

William Gager's Additions to Seneca's Hippolytus

$\mathrm{J} \cdot \mathrm{W}$. BINNS

Gasparo Contarini and His Friends

J. B. ROSS

Chapman's Ovids Banquet of Sence and the Emblematic Tradition RHODA M. RIBNER 